\title{
Short communication: Characterization of the milk protein expression profiles in dairy buffaloes with and without subclinical mastitis
}

\author{
Fernanda Tanamati, ${ }^{1} \odot$ Jeremy F. Taylor, ${ }^{2} \odot$ Susanta K. Behura, ${ }^{2}$ Daniel J. A. Santos, ${ }^{3} \odot$

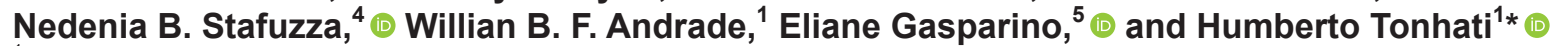 \\ ${ }^{1}$ Department of Animal Science, São Paulo State University (FCAV/UNESP), Jaboticabal 14884-900, Brazil \\ ${ }^{2}$ Division of Animal Sciences, University of Missouri, Columbia 65211 \\ ${ }^{3}$ Department of Animal and Avian Sciences, University of Maryland, College Park 20742 \\ ${ }^{4}$ Institute of Animal Science (IZ), Sertãozinho 14174-000, Brazil \\ ${ }^{5}$ Department of Animal Sciences, Maringá State University (UEM), Maringá 87020-900, Brazil
}

\begin{abstract}
The aim of this study was to characterize the proteins present in milk whey from buffaloes with and without subclinical mastitis using a proteomic approach to identify differentially expressed proteins as potential biomarkers for this disease. Whey from Murrah buffaloes with subclinical mastitis was compared with whey from healthy animals using liquid chromatography-tandem mass spectrometry. The annotated protein databases for Bubalus bubalis and Bos taurus were used in the analysis, and the gene annotations from the buffalo and bovine reference assemblies were also used. After integrating gene annotations from both buffaloes and bovines, a total of 1,033 proteins were identified, of which 156 were differentially expressed. Eighteen biological processes were annotated with Gene Ontology. Cathelicidin-3 was identified as a potential biomarker for subclinical mastitis. These results are important to the characterization of mastitis in the buffalo mammary gland and may aid in the development of tools for early diagnosis.
\end{abstract}

Key words: Bubalus bubalis, cathelicidin-3, milk whey protein, proteomics

\section{Short Communication}

Milk is an important source of nutrients and a key ingredient in the production of several dairy food products. The high levels of protein and fat in the milk of buffaloes, approximately 4.27 and $6.84 \%$, respectively (Aspilcueta-Borquis et al., 2010), ensure high yields from the processing of the milk and its derivatives.

Received May 4, 2019.

Accepted November 19, 2019.

*Corresponding author: tonhati@fcav.unesp.br
However, diseases such as mastitis change milk composition, making it less suitable for processing and human consumption and significantly reducing the value of affected milk (Rainard and Riollet, 2006).

Mastitis is characterized as an inflammation of the mammary gland in reaction to metabolic and physiological changes, trauma, or invasion of pathogenic agents (Oviedo-Boyso et al., 2007). As a result, an increase in SCC, mainly neutrophils, occurs during the inflammatory process that follows the infection of mammary gland tissues (Oviedo-Boyso et al., 2007). Strategies for the preservation and improvement of udder health might be devised based on the protein profiles produced by these cells during the course of infection.

In dairy animals, proteomics has widely been used to analyze the milk fat globule membrane proteins $(\mathrm{Lu}$ et al., 2011), to benchmark proteins among different mammalian species (Yang et al., 2013), and to investigate the effects of high SCC on milk proteins (Zhang et al., 2015). Other studies have used proteomics to identify protein biomarkers in bovine milk from cows with mastitis (Hogarth et al., 2004; Pongthaisong et al., 2016), and comparisons have been made between the expression levels of proteins in milk produced by dairy cows with and without mastitis (Hogarth et al., 2004; Li et al., 2014).

Relatively few studies have been conducted on the milk proteome of buffaloes with mastitis. However, studies that have searched for protein biomarkers differentially expressed in the milk of animals with and without mastitis can assist in the development of biomarkers for the early diagnosis of this disease, enabling improved animal welfare as well as improvements in the quality and safety of produced milk. Therefore, the aims of this study were to verify protein profile changes present in the milk whey of buffaloes with and without subclinical mastitis, to determine which proteins are differentially expressed, and to identify potential 
biomarkers of subclinical mastitis to aid in the early detection of this disease.

Milk samples used in this study were collected from 16 Murrah buffalo cows from a farm located in Registro, São Paulo State, Brazil, and supplied by the Buffalo Milk Control program of the São Paulo State University (Jaboticabal, Brazil). All animals were grazed on Brachiaria decumbens pastures and supplemented with soybean meal and corn concentrate; calved in March or April; and were in the initial third of lactation, with an average milk yield of $7 \mathrm{~kg} / \mathrm{d}$. Eight milk samples were collected from animals without subclinical mastitis (healthy group) and 8 were collected from animals with subclinical mastitis (subclinical mastitis group) that was not experimentally induced. The samples were collected from one quarter, directly from the buffalo teats, in the morning at the beginning of milking. Before collection, the buffalo's teats were washed with running water and then immediately dried with a paper towel. The first method used to determine which animals were healthy or affected by subclinical mastitis was the California Mastitis Test; a negative result indicated no sign of infection (i.e., the solution did not show precipitation), and a positive result indicated that the sample was positive for mastitis (i.e., presented a very viscous liquid and coagulated particles or was gelatinous and completely coagulated). After the California Mastitis Test, milk samples were collected for SCC, microbiological culture, and proteome analysis. For SCC, aliquots of milk from each animal were collected for somatic cell counting by flow cytometry using a SomaCount 300 (Bentley Instruments Inc., Chaska, $\mathrm{MN})$. For proteomic analysis, $20 \mathrm{~mL}$ of milk from each animal was collected in a sterile tube and transported on dry ice in isothermal containers to the laboratory, where it was stored in a freezer at $-80^{\circ} \mathrm{C}$.

The SCC was used to confirm each animal's California Mastitis Test mastitis diagnosis, with a maximum SCC value of $\leq 101 \times 10^{3}$ cells $/ \mathrm{mL}$ for buffaloes without mastitis and a minimum SCC value of $\geq 2,310$ $\times 10^{3}$ cells $/ \mathrm{mL}$ for buffaloes with mastitis. Milk microbiological culture was performed for all samples, and the animals with subclinical mastitis were found to be infected with the pathogens Streptococcus dysgalactiae, Streptococcus uberis, Corynebacterium bovis, and Streptococcus agalactiae.

Milk proteome analysis was performed at the Veritas Life Sciences biotechnology company at USP Technology Park of Ribeirao Preto, São Paulo State, Brazil. First, the samples were thawed in the refrigerator for $6 \mathrm{~h}$. Then, $10 \mu \mathrm{L}$ of protease inhibitor cocktail (SigmaAldrich, St. Louis, MO) was added to $1 \mathrm{~mL}$ of each sample. Samples were centrifuged at $3,000 \times g$ for 15 min at $4^{\circ} \mathrm{C}$ for the removal of milk fat. The resulting skim milk was subjected to further centrifugation at $13,000 \times g$ for $4 \mathrm{~h}$ to obtain the whey proteins in the supernatant. Approximately $500 \mu \mathrm{L}$ of each sample was subjected to casein precipitation, using $50 \mu \mathrm{L}$ of $0.5 \mathrm{M}$ acetic acid to obtain a $\mathrm{pH}$ of 4.6. Centrifugation was performed at $3,000 \times g$ for 5 min at $4^{\circ} \mathrm{C}$, and the supernatant was separated for proteomic analysis. Protein quantification was performed using the Bradford assay protocol. Sodium dodecyl sulfate-PAGE was used to evaluate the protein profile. For mass spectrometry, 50 $\mu \mathrm{g}$ of each sample was prepared, which consisted of 3 primary steps: (1) reduction and alkylation of proteins, (2) enzymatic digestion of the proteins with trypsin, and (3) clean-up and desalting of the samples. Briefly, disulfide bonds of the proteins present within each sample were reduced by the addition of dithiothreitol (SigmaAldrich) in the proportion of $1 \mathrm{mg}$ of dithiothreitol/mg of protein and incubation for $2 \mathrm{~h}$ at room temperature. This was followed by the addition of the alkylating agent iodoacetamide (Sigma-Aldrich) in the proportion of $3 \mathrm{mg}$ of iodoacetamide/mg of protein and incubation for $1 \mathrm{~h}$ at room temperature in the dark. The sample volume was diluted 5 times in $0.1 \mathrm{M}$ ammonium bicarbonate solution $(\mathrm{pH} \geq 8.0)$ to achieve a final volume of $500 \mu \mathrm{L}$. The samples were incubated with $1 \mu \mathrm{g}$ of sequencing grade modified trypsin (Promega, Madison, WI) at $37^{\circ} \mathrm{C}$ overnight. Before sample analysis in the mass spectrometer, the samples were cleaned up and desalted using an Oasis HLB Cartridge $1-\mathrm{cm}^{3}$ column (Waters, Milford, MA) according to the manufacturer's recommendations. Briefly, the column was equilibrated with $5 \%$ acetonitrile solution containing $0.1 \%$ formic acid, and the protein fraction was eluted with $80 \%$ acetonitrile. Samples were dried in a SpeedVac (Thermo Fisher Scientific, Carlsbad, CA), and approximately 1 $\mu \mathrm{g}$ of each digested sample was used for analysis, in duplicate, using nanoflow liquid chromatography coupled to LTQ Orbitrap Elite (Thermo-Finnigan, San Jose, CA) tandem MS. The liquid chromatography separation was performed in a PicoFrit $25-\mathrm{cm}$ column (75 $\mu \mathrm{m}$ i.d.; New Objective, Woburn, MA), in-house packed with Magic C18 (Dr. Maisch GmbH, Ammerbuch-Entringen, Baden-Württemberg, Germany), using a 60-min linear gradient from 5 to $40 \%$ of acetonitrile in $0.1 \%$ formic acid at $250 \mathrm{~nL} / \mathrm{min}$. The spectra were acquired in a data-dependent mode in the 400 to 1,800 mass:charge ratio $(\mathrm{m} / \mathrm{z})$ range, and the 5 most abundant +2 or +3 ions of each MS spectrum were selected for MS/MS analysis. The mass spectrometer parameters were as follows: capillary voltage of $2.2 \mathrm{kV}$, at $200^{\circ} \mathrm{C}$, resolution of 100,000, and Fourier transform target value of $2,000,000$. 
Obtained data were processed with the Computational Proteomics Analysis System (Rauch et al., 2006) using the X! Tandem search algorithm. The annotated protein database for Bubalus bubalis available at NCBI (https://www.ncbi.nlm.nih.gov/protein) and annotated protein database for Bos taurus available on UniProt (http://www.uniprot.org/) were used for this analysis. The comparative and quantitative analyses were performed using the number of peptide-spectrum matches observed per peptide, which provides an estimate of abundance, also known as spectral counting.

Gene annotations from the buffalo and bovine reference assemblies were used. The water buffalo has 2 reference genomes (Tantia et al., 2011; Zimin et al., 2013) available at NCBI and a reference set of transcripts produced using RNA-sequencing from 30 different tissues (Strozzi et al., 2013); however, the buffalo genome is not fully annotated. To compensate for this deficiency, the bovine annotation, which is of a higher quality than that for the buffalo, was also considered. The annotated proteins identified for buffaloes and bovines were organized according to their respective gene symbol, and the gene symbols were grouped according to their spectral counts. If gene isoforms were on the same annotation and had the same number of counts, only one was considered. When the same gene symbol was identified for bovine and buffalo, the buffalo annotation was considered regardless of whether the counts were identical. For buffalo and bovine gene isoforms that were annotated with different counts, graphs were plotted and the trendline and coefficient of determination $\left(\mathbf{R}^{2}\right)$ values were considered. For values of $\mathbf{R}^{2}$ $\geq 0.95$ only the isoform with the highest counts was considered, and for $\mathrm{R}^{2}$ values $<0.95$ all of the isoforms were considered.

Statistical analysis of differentially expressed proteins (DEP) was performed using the msmsTests package from Bioconductor (Gregori et al., 2013) based on R statistical software (R Core Team, 2013), in which the negative binomial distribution used in the edgeR package for transcript expression analysis is available. Correction for multiple testing was achieved using the false discovery rate with differential protein expression declared for those tests yielding a false discovery rate $<0.05$. The Gene Ontology Consortium (http: //geneontology.org/) powered by Protein Analysis through Evolutionary Relationships (PANTHER) Classification System version 12.0 (http://pantherdb .org/) was used to interpret the biological functions of the differentially expressed proteins. To identify protein biomarkers, the R/Bioconductor package "minet" (Meyer et al., 2008) and the keyplayer package (An and Liu, 2016) were used. To identify potential biomarkers,
Z-scores were calculated from the difference between mean peptide counts between animals in the healthy and subclinical mastitis groups and the standard error of the difference (Pleil, 2016).

A total of 1,993 proteins were identified, of which 1,044 were identified using the buffalo reference assembly and 949 were identified using the bovine reference assembly. Using the buffalo reference, 493 proteins were present only in the mastitis group, 362 in the mastitis and control groups, and 189 only in the control group. Using the bovine reference, a total of 436 proteins were identified only in the mastitis group, 393 in the mastitis and control groups, and 120 only in the control group.

Duplicate gene annotations generated from both the buffalo and bovine reference assemblies were reduced to that from the buffalo annotation. Following the elimination of duplicate annotations, the total number of annotated proteins was 1,033; of those, 252 were identified in both the buffalo and bovine reference genome annotations, 304 were unique to bovine, and 477 were unique to buffalo. In addition, the largest number of proteins (524) was identified only in the mastitis group, followed by 368 in both the mastitis and control groups, and finally the fewest (141) only in the control group. Of the 1,033 expressed proteins, 156 (15.1\%) were predicted to be differentially expressed (Table 1), and of these, 64 were found exclusively in the milk of buffaloes with mastitis. This number of proteins predicted to be unique to animals with mastitis suggests a global change in the milk protein profiles of affected animals.

The 3 proteins with the highest absolute log-fold change values were leukocyte elastase inhibitor (encoded by SERPINB1), cathelicidin-2-like (LOC102413933), and $\alpha$-enolase (ENO1). These 3 proteins are directly or indirectly related to the immune defense system.

The log-fold change values were used to partition the DEP into those that were up- or downregulated; 32 of the DEP were downregulated and 124 were upregulated in the animals with subclinical mastitis relative to the healthy animals. Surprisingly, we observed that all 6 differentially expressed cathelicidins were upregulated and all 16 differentially expressed keratins were downregulated in the animals with subclinical mastitis.

The gene symbols for the $156 \mathrm{DEP}$ were analyzed to identify their biological processes (Table 2). We identified several functions related to the immune system and metabolic processes. The identification of functions such as glycolytic process, mesenchymal migration, and glucose metabolic processes suggests that mastitis broadly affects the normal metabolic functions of dairy buffaloes. Several functions and proteins, such as lactoferrin, which is related to the immune defense system, were expected to be found among the DEP. Lactoferrin 
Table 1. Proteins that were predicted to be differentially expressed in the milk of buffaloes with or without mastitis

\begin{tabular}{|c|c|c|c|c|}
\hline Gene symbol & Protein name & $\log \mathrm{FC}^{1}$ & $P$-value & Q-value \\
\hline ACTA 1 & Actin, $\alpha$ skeletal muscle & 2.850 & $1.33 \mathrm{E}-06$ & $1.30 \mathrm{E}-05$ \\
\hline ACTA2 & Actin, aortic smooth muscle & 2.829 & $1.36 \mathrm{E}-05$ & 0.00011 \\
\hline$A C T B L 2$ - isoform 1 & $\beta$-Actin-like protein 2 isoform $\mathrm{X} 1$ & 2.436 & $2.72 \mathrm{E}-06$ & $2.54 \mathrm{E}-05$ \\
\hline$A C T B L 2$ - isoform 2 & $\beta$-Actin-like protein 2 isoform $\mathrm{X} 2$ & 1.717 & 0.00302 & 0.01115 \\
\hline ACTC1 & Actin, $\alpha$ cardiac muscle 1 & 2.904 & $8.79 \mathrm{E}-07$ & $9.72 \mathrm{E}-06$ \\
\hline$A P O E$ & Apolipoprotein E isoform X1 & 3.515 & 1.19E-06 & $1.20 \mathrm{E}-05$ \\
\hline C4 & Complement $\mathrm{C} 4$ & 2.248 & 0.00296 & 0.01104 \\
\hline CD109 & Uncharacterized protein & -2.221 & 0.01815 & 0.04340 \\
\hline$C F B$ & Complement factor B & 1.684 & $4.87 \mathrm{E}-05$ & 0.00032 \\
\hline $\mathrm{CFH}$ & Complement factor $\mathrm{H}$ & 1.646 & 0.00775 & 0.02344 \\
\hline$C L U$ & Clusterin & 1.050 & $4.92 \mathrm{E}-06$ & $4.25 \mathrm{E}-05$ \\
\hline$E Z R$ & Ezrin & 2.139 & 0.00627 & 0.01946 \\
\hline$F G A$ & Fibrinogen $\alpha$ chain & 1.573 & 0.00223 & 0.00951 \\
\hline$F G B$ & Fibrinogen $\beta$ chain, partial & 1.808 & 0.00944 & 0.02761 \\
\hline$H C N 1$ & $\begin{array}{l}\text { Potassium/sodium hyperpolarization-activated cyclic } \\
\text { nucleotide-gated channel 1-like }\end{array}$ & 2.899 & 0.00574 & 0.01815 \\
\hline$H P$ & Haptoglobin & 3.776 & $6.14 \mathrm{E}-08$ & $9.53 \mathrm{E}-07$ \\
\hline$H P X$ & Hemopexin & 0.903 & 0.01884 & 0.04477 \\
\hline HSPA 8 & Heat shock cognate $71 \mathrm{kda}$ protein & 2.397 & 0.00605 & 0.01895 \\
\hline IGHE & Uncharacterized protein & 3.252 & 0.00056 & 0.00274 \\
\hline IGJ & Immunoglobulin J chain & 1.897 & 0.00241 & 0.00996 \\
\hline IGLL1 & Uncharacterized protein & 1.171 & 0.00244 & 0.00996 \\
\hline $\mathrm{ITIH}_{4}$ & Inter- $\alpha$-trypsin inhibitor heavy chain $\mathrm{H} 4$ & 2.232 & 0.00048 & 0.00241 \\
\hline$J C H A I N$ & Immunoglobulin J chain & 2.017 & 0.00119 & 0.00547 \\
\hline KRT10 & Keratin, type I cytoskeletal 10 & -1.950 & 0.00342 & 0.01223 \\
\hline KRT36 & Keratin, type I cuticular Ha6 & -2.075 & 0.01524 & 0.03772 \\
\hline KRT37 & Low quality protein: keratin, type I cuticular $\mathrm{Ha} 7$ & -2.075 & 0.01524 & 0.03772 \\
\hline KRT38 & Keratin, type I cuticular $\mathrm{Ha} 8$ & -2.075 & 0.01524 & 0.03772 \\
\hline KRT40 & Keratin, type I cytoskeletal 40 & -2.075 & 0.01524 & 0.03772 \\
\hline KRTr6 & Keratin, type II cytoskeletal 2 oral & -2.513 & 0.00863 & 0.02545 \\
\hline KRT9 & Keratin, type I cytoskeletal 9 & -1.021 & 0.02113 & 0.04825 \\
\hline$L A L B A$ & $\alpha-\mathrm{LA}$ & -0.589 & 0.00044 & 0.00230 \\
\hline$L A M B 1$ & Laminin subunit $\beta-1$ & -2.460 & 0.01169 & 0.03285 \\
\hline LCN2 & Neutrophil gelatinase-associated lipocalin isoform X1 & 3.928 & $3.31 \mathrm{E}-08$ & $5.58 \mathrm{E}-07$ \\
\hline$L D H A$ & L-Lactate dehydrogenase A chain & 2.145 & 0.00834 & 0.02481 \\
\hline$L D H B$ & L-Lactate dehydrogenase B chain & 1.960 & 0.00042 & 0.00222 \\
\hline$L G B$ & $\beta-L G$ & -0.407 & 0.01035 & 0.02931 \\
\hline LOC100297192 & Uncharacterized protein & 1.328 & 0.00376 & 0.01291 \\
\hline LOC102389131 & $\begin{array}{l}\text { Keratin, type I microfibrillar } 48 \mathrm{kda} \text {, component 8C-1- } \\
\text { like }\end{array}$ & -2.075 & 0.01524 & 0.03772 \\
\hline LOC102389471 & $\begin{array}{l}\text { Keratin, type I microfibrillar } 48 \mathrm{kda} \text {, component 8C-1- } \\
\text { like }\end{array}$ & -2.075 & 0.01524 & 0.03772 \\
\hline LOC102390213 & $\begin{array}{l}\text { Putative V-set and immunoglobulin domain-containing- } \\
\text { like protein IGHV4OR15-8-like, partial }\end{array}$ & 2.028 & 0.02102 & 0.04825 \\
\hline LOC102390936 & Peptidyl-prolyl cis-trans isomerase A-like & 3.811 & $2.40 \mathrm{E}-05$ & 0.00018 \\
\hline LOC102391101 & Thioredoxin-like & 2.472 & 0.01031 & 0.02931 \\
\hline LOC102395699 & $\alpha$-S2-CN-like & 1.062 & 0.00485 & 0.01574 \\
\hline
\end{tabular}


Table 1 (Continued). Proteins that were predicted to be differentially expressed in the milk of buffaloes with or without mastitis

\begin{tabular}{|c|c|c|c|c|}
\hline Gene symbol & Protein name & $\operatorname{LogFC}{ }^{1}$ & $P$-value & Q-value \\
\hline$L O C 102403576$ & $\begin{array}{l}\text { Putative V-set and immunoglobulin domain-containing- } \\
\text { like protein IGHV4OR15-8-like, partial }\end{array}$ & 2.028 & 0.02102 & 0.04825 \\
\hline LOC102404617 & Peptidyl-prolyl cis-trans isomerase A-like & 3.787 & $2.67 \mathrm{E}-05$ & 0.00019 \\
\hline LOC102406615 & $\beta$-LG-like isoform X1 & -0.381 & 0.00464 & 0.01520 \\
\hline LOC102409057 & Serum amyloid A protein-like isoform X1 & 2.542 & 0.00380 & 0.01293 \\
\hline LOC102412066 & L-Lactate dehydrogenase B chain-like, partial & 1.738 & 0.01784 & 0.04297 \\
\hline LOC102413388 & Clusterin-like, partial & 0.718 & 0.00355 & 0.01257 \\
\hline LOC102414975 & Heat shock cognate $71 \mathrm{kda}$ protein-like & 2.095 & 0.01589 & 0.03907 \\
\hline LOC102416562 & Fibrinogen gamma-B chain-like & 1.554 & 0.00459 & 0.01517 \\
\hline LOC102416626 & Complement factor H-like, partial & 2.310 & 0.00674 & 0.02075 \\
\hline LOC104968478 & Serum amyloid A protein & 2.725 & 0.00046 & 0.00235 \\
\hline LOC617696 & Uncharacterized protein & 2.189 & 0.00518 & 0.01666 \\
\hline$P A E P$ & Uncharacterized protein & -0.462 & 0.01967 & 0.04629 \\
\hline PLBD2 & Putative phospholipase B-like 2 & -2.175 & 0.017834 & 0.04297 \\
\hline PPIA & Peptidyl-prolyl cis-trans isomerase A & 3.811 & $2.40 \mathrm{E}-05$ & 0.00018 \\
\hline$R D X$ & Radixin & 1.967 & 0.01500 & 0.03772 \\
\hline$S A A 1$ & Serum amyloid A protein & 2.626 & 0.00259 & 0.00999 \\
\hline SAA3 & Serum amyloid A protein & 2.752 & 0.00150 & 0.00674 \\
\hline SELENOM & Low quality protein: selenoprotein M-like & -1.601 & 0.00750 & 0.02290 \\
\hline SIL1 & Nucleotide exchange factor SIL1 & -2.983 & 0.00091 & 0.00429 \\
\hline TCN1 & Transcobalamin-1 & 3.049 & 0.00218 & 0.00942 \\
\hline TPP1 & Tripeptidyl-peptidase 1 & -2.830 & 0.00017 & 0.00101 \\
\hline$T X N$ & Thioredoxin & 2.472 & 0.01031 & 0.02931 \\
\hline \multicolumn{5}{|l|}{$\begin{array}{l}\text { Exclusive milk proteins } \\
\text { of buffaloes with } \\
\text { subclinical mastitis }\end{array}$} \\
\hline CATHL7 & Cathelicidin-7 & 5.482 & $1.77 \mathrm{E}-09$ & $5.68 \mathrm{E}-08$ \\
\hline$C D 177$ & Low quality protein: CD177 antigen & 5.007 & 3.69E-09 & $1.01 \mathrm{E}-07$ \\
\hline CFL1 & Cofilin-1 & 4.237 & $9.47 \mathrm{E}-06$ & $7.98 \mathrm{E}-05$ \\
\hline CFL2 & Cofilin-2 & 2.986 & 0.00362 & 0.01270 \\
\hline CHI3L1 & Chitinase-3-like protein 1 & 5.665 & $2.34 \mathrm{E}-09$ & $6.89 \mathrm{E}-08$ \\
\hline ENO1 & $\alpha$-Enolase & 6.323 & $2.86 \mathrm{E}-13$ & $2.53 \mathrm{E}-11$ \\
\hline ENO2 & ENO2 protein & 3.864 & $4.28 \mathrm{E}-05$ & 0.00029 \\
\hline ENO3 & $\beta$-Enolase & 4.395 & $1.42 \mathrm{E}-06$ & $1.36 \mathrm{E}-05$ \\
\hline ENSBTAG00000009580 & Uncharacterized protein & 3.157 & 0.00170 & 0.00743 \\
\hline FABP5 & Fatty acid-binding protein, epidermal & 4.012 & $4.81 \mathrm{E}-05$ & 0.00032 \\
\hline$G A P D H$ & GAPDH & 4.421 & $9.73 \mathrm{E}-07$ & $1.01 \mathrm{E}-05$ \\
\hline$G P I$ & Glucose-6-phosphate isomerase & 5.365 & $5.84 \mathrm{E}-09$ & $1.29 \mathrm{E}-07$ \\
\hline HIST1H1A & Histone H1.1 & 3.065 & 0.00253 & 0.00996 \\
\hline HISTIH1C & Histone H1.2 & 3.398 & 0.00057 & 0.00274 \\
\hline HIST1H1D & Histone H1.3 & 3.065 & 0.00253 & 0.00996 \\
\hline HIST1H1E & HIST1H1E protein & 3.726 & 0.00013 & 0.00078 \\
\hline$H M G N 2$ & Non-histone chromosomal protein HMG-17 & 3.725 & 0.00019 & 0.00109 \\
\hline$H R G$ & Histidine-rich glycoprotein & 4.996 & $9.20 \mathrm{E}-07$ & $9.87 \mathrm{E}-06$ \\
\hline$L C P 1$ & Plastin-2 & 5.042 & $1.36 \mathrm{E}-07$ & $1.84 \mathrm{E}-06$ \\
\hline LOC102390145 & Histone H1.2-like & 3.398 & 0.00057 & 0.00274 \\
\hline LOC102390920 & Histone H1.1-like & 3.065 & 0.00253 & 0.00996 \\
\hline LOC102391467 & $15 \mathrm{kda}$ protein B-like & 3.720 & 0.00041 & 0.00218 \\
\hline
\end{tabular}


Table 1 (Continued). Proteins that were predicted to be differentially expressed in the milk of buffaloes with or without mastitis

\begin{tabular}{|c|c|c|c|c|}
\hline Gene symbol & Protein name & $\operatorname{LogFC}{ }^{1}$ & $P$-value & Q-value \\
\hline LOC102400550 & Thymosin $\beta$-10-like & 4.297 & $3.89 \mathrm{E}-06$ & $3.44 \mathrm{E}-05$ \\
\hline LOC102400767 & GAPDH-like, partial & 3.028 & 0.00265 & 0.00999 \\
\hline LOC102402381 & Cathelicidin-5-like & 4.709 & $5.24 \mathrm{E}-07$ & $5.99 \mathrm{E}-06$ \\
\hline LOC102403908 & Glucose-6-phosphate isomerase-like & 3.005 & 0.00342 & 0.01223 \\
\hline LOC102408803 & Histone H1.4-like & 3.726 & 0.00013 & 0.00078 \\
\hline LOC102412295 & Cathelicidin-4-like & 5.373 & $2.05 \mathrm{E}-08$ & $3.62 \mathrm{E}-07$ \\
\hline LOC102412313 & Histone H1.3-like & 3.065 & 0.00253 & 0.00996 \\
\hline LOC102413454 & Peptidyl-prolyl cis-trans isomerase A-like & 3.241 & 0.00139 & 0.00632 \\
\hline LOC102413623 & Cathelicidin-7-like & 4.532 & $2.36 \mathrm{E}-05$ & 0.00018 \\
\hline LOC102413933 & Cathelicidin-2-like & 6.787 & $1.78 \mathrm{E}-16$ & $3.14 \mathrm{E}-14$ \\
\hline LOC102414941 & Cathelicidin-6-like & 5.533 & $4.66 \mathrm{E}-09$ & $1.17 \mathrm{E}-07$ \\
\hline$P N P$ & Purine nucleoside phosphorylase & 4.084 & $3.05 \mathrm{E}-05$ & 0.00022 \\
\hline$S D S$ & L-Serine dehydratase/L-threonine deaminase & 5.318 & $1.45 \mathrm{E}-08$ & $2.69 \mathrm{E}-07$ \\
\hline SERPINB1 & Leukocyte elastase inhibitor & 6.898 & $1.03 \mathrm{E}-22$ & $3.66 \mathrm{E}-20$ \\
\hline SERPINB6 & Serpin B6 & 3.541 & 0.00025 & 0.00135 \\
\hline SERPINB8 & Serpin B8 & 3.541 & 0.00025 & 0.00135 \\
\hline SERPINI2 & SERPINI2 protein & 3.541 & 0.00025 & 0.00135 \\
\hline SH3BGRL3 & SH3 domain-binding glutamic acid-rich-like protein 3 & 3.506 & 0.00047 & 0.00239 \\
\hline TAGLN2 & Transgelin-2 & 3.385 & 0.00096 & 0.00446 \\
\hline$T K T$ & Transketolase & 5.737 & $1.27 \mathrm{E}-09$ & $4.49 \mathrm{E}-08$ \\
\hline TMSB10 & Thymosin $\beta-10$ & 4.297 & $3.89 \mathrm{E}-06$ & $3.44 \mathrm{E}-05$ \\
\hline$T M S B 4 X$ & Thymosin $\beta-4$ & 5.177 & $4.96 \mathrm{E}-09$ & $1.17 \mathrm{E}-07$ \\
\hline TPI1 & Triosephosphate isomerase & 3.852 & 0.00020 & 0.00114 \\
\hline
\end{tabular}

${ }^{1} \log \mathrm{FC}=\log _{2}$ fold change. Fold change estimates are relative to the subclinical mastitis group.

${ }^{2}$ Spectral counts of control group $=0$.

is present in 6 annotated biological processes and plays a key role in antimicrobial, anticarcinogenic, and antiinflammatory activities (García-Montoya et al., 2012).

The 3 proteins identified as potential biomarkers were cathelicidin-3 (CATHL3), chitinase-3-like protein 1 (CHI3L1), and keratin, type I cytoskeletal 18 (KRT18). Cathelicidin-3 and chitinase-3-like protein 1 were present only in the animals with mastitis and were upregulated in those animals. Conversely, keratin, type I cytoskeletal 18 was present in both groups of animals but was downregulated in the subclinical mastitis group. If cathelicidin-3 can be shown to not be expressed in the milk of healthy animals, this protein would appear to provide a useful biomarker for subclinical mastitis in Murrah buffaloes (Z-score $=3.6 ; P<0.05$ ).

The cathelicidins comprise a family of antimicrobial peptides that contain a conserved $\mathrm{N}$-terminal sequence (the "cathelin" domain) and a C-terminal cationic antimicrobial domain (Zanetti, 2004). In dairy cows, cathelicidin-1, cathelicidin-2, cathelicidin-3, and cathelicidin- 4 have previously been found in milk with mastitis after infection with Escherichia coli (Boehmer et al., 2008), and cathelicidin-1 has previously been described as a biomarker for the detection of subclinical mastitis caused by natural Streptococcus agalactiae infection (Pongthaisong et al., 2016). In caprines, Olumee-Shabon et al. (2013) identified the presence of cathelicidin-1 and cathelicidin-3 in the milk of induced endotoxin mastitis animals. Although in our results the natural disease is caused by different pathogens, an investigation by Addis et al. (2017) has suggested that, depending on the causative microorganism, the cathelicidin abundance in milk may be affected without compromising the efficiency of this protein as a potential biomarker for the disease. These results in other dairy species consistently support the importance of the cathelicidin family to mastitis, which is validated by the results of the present study.

Another important protein, CHI3L1, plays a key role in the antipathogen response, participating in the innate immune response at the site of pathogen invasion (Di Rosa et al., 2013). The study by Smolenski et al. 
Table 2. Gene Ontology (GO) terms identified using the Gene Ontology Consortium (http://geneontology.org/) powered by the PANTHER Classification System (http://pantherdb.org/)

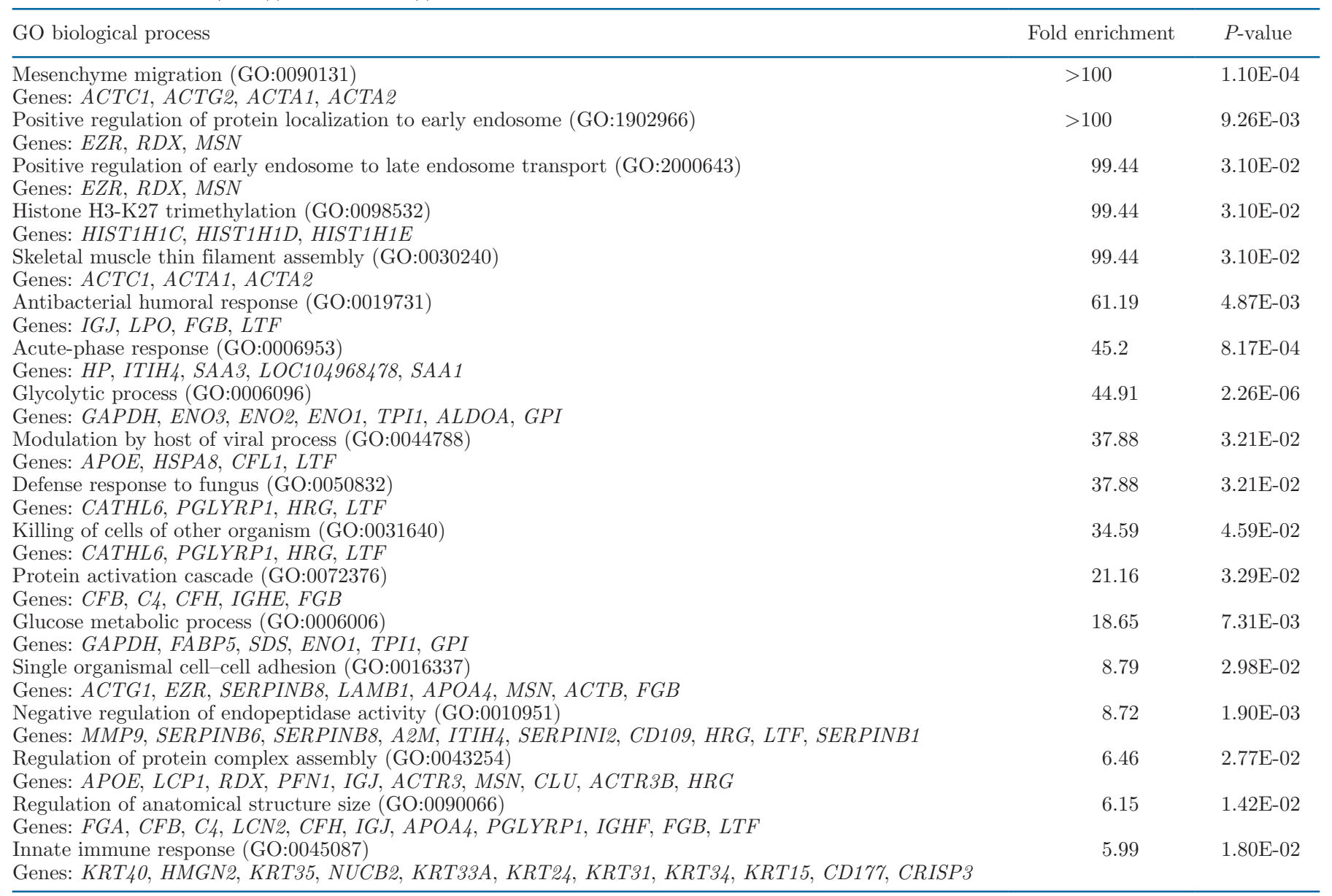

(2014) demonstrated the presence of chitinase-3-like protein-1 in the milk of cows infected by Streptococcus uberis and, as found here, chitinase-3-like protein 1 was identified only in the whey protein from bovine milk with experimentally induced coliform mastitis (Boehmer et al., 2010).

In conclusion, the changes in buffalo milk whey caused by subclinical mastitis are due to the expression of a relatively large number of proteins. We found 156 proteins to be differentially expressed in the milk whey of buffaloes with and without subclinical mastitis, of which cathelicidin-3 appears to be a useful biomarker for subclinical mastitis. These results are important for the study of mastitis in these animals, and the presence of cathelicidin-3 only in the milk of buffaloes with mastitis may assist in developing strategies for the early diagnosis of the disease. Future research exploring the expression of cathelicidin-3 and other cathelicidins in the milk of buffaloes with subclinical mastitis is needed to elucidate the inflammation mechanisms in the affected mammary gland.

\section{ACKNOWLEDGMENTS}

The authors thank the São Paulo Research Foundation (FAPESP, Brazil) for providing financial support (grants \#2014/19321-4, \#2014/25309-7, and \#2016/10526-8) to conduct the research project, the National Council of Technological and Scientific Development $(\mathrm{CNPq})$ for providing productivity research fellowships for Eliane Gasparino and Humberto Tonhati, and the Animal Science Graduate Programs at Maringá State University (UEM), Maringá, Brazil, and São Paulo State University (FCAV/UNESP), Jaboticabal, Brazil. We thank the Division of Animal Sciences, University of Missouri (Columbia), for accepting the first author as a visiting scholar. The authors have not stated any conflicts of interest.

\section{REFERENCES}

Addis, M. F., V. Bronzo, G. M. G. Puggioni, C. Cacciotto, V. Tedde, D. Pagnozzi, C. Locatelli, A. Casula, G. Curone, S. Uzzau, and P. Moroni. 2017. Relationship between milk cathelicidin abun- 
dance and microbiologic culture in clinical mastitis. J. Dairy Sci. 100:2944-2953. https://doi.org/10.3168/jds.2016-12110.

An, W., and Y. H. Liu. 2016. keyplayer: An R package for locating key players in social networks. R J. 8:257-268. https://doi.org/10 $.32614 / \mathrm{RJ}-2016-018$.

Aspilcueta-Borquis, R. R., F. R. Araujo Neto, F. Baldi, A. B. Bignardi, L. G. Albuquerque, and H. Tonhati. 2010. Genetic parameters for buffalo milk yield and milk quality traits using Bayesian inference. J. Dairy Sci. 93:2195-2201. https://doi.org/10.3168/jds .2009-2621.

Boehmer, J. L., D. D. Bannerman, K. Shefcheck, and J. L. Ward. 2008. Proteomic analysis of differentially expressed proteins in bovine milk during experimentally induced Escherichia coli mastitis. J. Dairy Sci. 91:4206-4218. https://doi.org/10.3168/jds.2008-1297.

Boehmer, J. L., J. A. DeGrasse, M. A. McFarland, E. A. Tall, K. J. Shefcheck, J. L. Ward, and D. D. Bannerman. 2010. The proteomic advantage: Label-free quantification of proteins expressed in bovine milk during experimentally induced coliform mastitis. Vet. Immunol. Immunopathol. 138:252-266. https://doi.org/10 $.1016 /$ j.vetimm.2010.10.004.

Di Rosa, M., G. Malaguarnera, C. De Gregorio, F. Drago, and L. Malaguarnera. 2013. Evaluation of CHI3L-1 and CHIT-1 expression in differentiated and polarized macrophages. Inflammation 36:482-492. https://doi.org/10.1007/s10753-012-9569-8.

García-Montoya, I. A., T. S. Cendón, S. Arévalo-Gallegos, and Q. Rascón-Cruz. 2012. Lactoferrin a multiple bioactive protein: An overview. Biochim. Biophys. Acta 1820:226-236. https://doi.org/ 10.1016/j.bbagen.2011.06.018.

Gregori, J., A. Sánchez, and J. Villanueva. 2013. msmsTests: LC-MS/ MS Differential Expression Tests. R package version 1.14.0. Accessed Nov. 2017. https://bioconductor.statistik.tu-dortmund.de/ packages $/ 3.5 / \mathrm{bioc} /$ manuals/msmsTests/man/msmsTests.pdf.

Hogarth, C. J., J. L. Fitzpatrick, A. M. Nolan, F. J. Young, A. Pitt, and P. D. Eckersall. 2004. Differential protein composition of bovine whey: A comparison of whey from healthy animals and from those with clinical mastitis. Proteomics 4:2094-2100. https://doi .org/10.1002/pmic.200300723.

Li, X., X. Z. Ding, Y. L. Wan, Y. M. Liu, and G. Z. Du. 2014. Comparative proteomic changes of differentially expressed whey proteins in clinical mastitis and healthy yak cows. Genet. Mol. Res. 13:6593-6601. https://doi.org/10.4238/2014.August.28.4.

Lu, J., S. Boeren, S. C. De Vries, H. J. F. Van Valenberg, J. Vervoort, and K. Hettinga. 2011. Filter-aided sample preparation with dimethyl labeling to identify and quantify milk fat globule membrane proteins. J. Proteomics 75:34-43. https://doi.org/10.1016/ j.jprot.2011.07.031.

Meyer, P. E., F. Lafitte, and G. Bontempi. 2008. minet: AR/Bioconductor package for inferring large transcriptional networks using mutual information. BMC Bioinformatics 9:461-470. https://doi .org/10.1186/1471-2105-9-461.

Olumee-Shabon, Z., T. Swain, E. A. Smith, E. Tall, and J. L. Boehmer. 2013. Proteomic analysis of differentially expressed proteins in caprine milk during experimentally induced endotoxin mastitis. J. Dairy Sci. 96:2903-2912. https://doi.org/10.3168/jds.2012-5956.

Oviedo-Boyso, J., J. J. Valdez-Alarcón, M. Cajero-Juárez, A. OchoaZarzosa, J. E. López-Meza, A. Bravo-Patino, and V. M. BaizabalAguirre. 2007. Innate immune response of bovine mammary gland to pathogenic bacteria responsible for mastitis. J. Infect. 54:399409. https://doi.org/10.1016/j.jinf.2006.06.010.

Pleil, J. D. 2016. Comparing biomarker measurements to a normal range: When to use standard error of the mean (SEM) or standard deviation (SD) confidence intervals tests. Biomarkers 21:195-199. https://doi.org/10.3109/1354750X.2015.1134666.

Pongthaisong, P., S. Katawatin, C. Thamrongyoswittayakul, and S. Roytrakul. 2016. Milk protein profiles in response to Streptococcus agalactiae subclinical mastitis in dairy cows. Anim. Sci. J. 87:92-98. https://doi.org/10.1111/asj.12391.

Rainard, P., and C. Riollet. 2006. Innate immunity of the bovine mammary gland. Vet. Res. 37:369-400. https://doi.org/10.1051/vetres: 2006007.

Rauch, A., M. Bellew, J. Eng, M. Fitzgibbon, T. Holzman, P. Hussey, M. Igra, B. Maclean, C. W. Lin, A. Detter, R. Fang, V. Faca, P. Gafken, H. Zhang, J. Whiteaker, D. States, S. Hanash, A. Paulovich, and M. W. McIntosh. 2006. Computational Proteomics Analysis System (CPAS): An extensible, open-source analytic system for evaluating and publishing proteomic data and high throughput biological experiments. J. Proteome Res. 5:112-121. https://doi .org/10.1021/pr0503533.

R Core Team. 2013. R: A language and environment for statistical computing. R Foundation for Statistical Computing, Vienna, Austria. http://www.R-project.org/.

Smolenski, G. A., M. K. Broadhurst, K. Stelwagen, B. J. Haigh, and T. T. Wheeler. 2014. Host defence related responses in bovine milk during an experimentally induced Streptococcus uberis infection. Proteome Sci. 12:19. https://doi.org/10.1186/1477-5956-12-19.

Strozzi, F., M. Picciolini, D. Iamartino, F. Ferre, G. Chillemi, A. Zimin, and J. Williams. 2013. The buffalo transcriptome. No. W113 in Proc. XXI Plant and Animal Genome Conference, San Diego, CA.

Tantia, M. S., R. K. Vijh, V. Bhasin, P. Sikka, P. K. Vij, R. S. Kataria, B. P. Mishra, S. P. Yadav, A. K. Pandey, R. K. Sethi, B. K. Joshi, S. C. Gupta, and K. M. L. Pathak. 2011. Whole-genome sequence assembly of the water buffalo (Bubalus bubalis). Indian J. Anim. Sci. 81:38-46.

Yang, Y., D. Bu, X. Zhao, P. Sun, J. Wang, and L. Zhou. 2013. Proteomic analysis of cow, yak, buffalo, goat and camel milk whey proteins: quantitative differential expression patterns. J. Proteome Res. 12:1660-1667. https://doi.org/10.1021/pr301001m.

Zanetti, M. 2004. Cathelicidins, multifunctional peptides of the innate immunity. J. Leukoc. Biol. 75:39-48. https://doi.org/10.1189/jlb .0403147 .

Zhang, L., S. Boeren, A. C. M. van Hooijdonk, J. M. Vervoort, and K. A. Hettinga. 2015. A proteomic perspective on the changes in milk proteins due to high somatic cell count. J. Dairy Sci. 98:5339-5351. https://doi.org/10.3168/jds.2014-9279.

Zimin, A. M. G., F. Ferre, T. Biagini, and S. Shroeder. 2013. The buffalo reference genome assembly. No. W110 in Proc. XXI Plant and Animal Genome Conference, San Diego, CA.

\section{ORCIDS}

Fernanda Tanamati ๑ https://orcid.org/0000-0001-9716-5343 Jeremy F. Taylor (ㄴ) https://orcid.org/0000-0002-6997-7245

Daniel J. A. Santos ๑ https://orcid.org/0000-0002-7062-3372

Nedenia B. Stafuzza @ \ttps://orcid.org/0000-0001-6432-2330

Eliane Gasparino 은 https://orcid.org/0000-0002-2611-9259

Humberto Tonhati @ https://orcid.org/0000-0003-4714-3167 